\title{
Unleashed Multi-culture on Untamed mind: An effect
}

\author{
Dr. Anindya Gangopadhyay
}

\begin{abstract}
It's very difficult to know exactly the root causes of a restrained mind. In global context different minds are embraced with different cultures, different habits, tastes and mind sets. Diversity in mixed culture sometimes represents a volatile state. Politics can work as balancing act in such a situation but most of the time it seems confused or rather becomes selfish in its own terms and conditions. Too good and seriously bad nuisances mostly occur. What does multi-culture produce? World literature portrays many moods of multi cultural society in its own way. A balancing act is always required in multi-cultured society but when it fails an endangered situation strikes out peace and harmony. Terrorism is nothing but an imbalance of a deformed mental stature mostly a cancer of mosaic culture. Present article is a small effort of searching out the actual situation of multiculturalism in context of world literature through analytical looking glass.
\end{abstract}

I dare. Dare to speak about fatal hazards of multiculturalism, a completely different sort of genre in context of literature. Past few decades it has acquired gradual importance in this global village. Feeling of ethnocentrism is a much relative term in courtyard of multiculturalism. It is the notion that one's culture is more sensible than or superior to that of other societies. If we think at its worst ethnocentrism has led people to commit ethnocide, the destruction of cultures. Superior feeling and too much aggressiveness is dreadful in ethnocide and genocide is bedfellow of it, the destruction of entire race. As we know that worst examples are too many in black pages of history which are no doubt very excruciating. Holocaust, the complete destruction of Jews in Europe by National Socialist German Workers' Party i.e. 'Nationalsozialistische Deutsche Arbeiterpartei', or NSDAP, commonly called Nazi party is shameful and terrifying example of genocide. The movement was culminated with the establishment of Third Reich, the totalitarian German state led by the dictator Adolf Hitler from 1933 to 1945. It remains always center of interest for world's renowned filmmakers and films like 'Atonement', 'The truce', 'The Boy in the striped pyjamas', 'Paragraph175', 'Schindler's list', 'Night and fog', 'Life is beautiful', 'Defiance', 'Amen', 'Europa europa', 'Black book', 'Sophie Scholl: The Final Days' there are endless in list. Each one is scrivener of genocide, the fatal hazard of multiculturalism. Ideological perspective may be politicized and may express harsh reactions. In that case cruel one can be represented as peacemaker in text book of school; people at ruined situation away from their native land can be politically provoked for extreme agitation so that they can extricate their rights, sometimes birthright after facing extrusion. But this ideological prologue can reproduce ethnocentric behavioral fallacy and some ever never changeable disorder in human psychology. Bengal after partition has faced certain kind of sustainable ethnocentric nonsense which can never be solved due to untamed minds but that demands few more words for analysis.

Multi-culture, mixed-culture, cross-culture there are many terms to express this transitional volatile state. It has made its room in various literatures sometimes dominantly and sometimes in recessive mode. Usually in social anthropology the matter is exemplified many a times by salad bowl containing a mixture of different vegetables, and sauce or sometimes by mixture of baked crunchy rice grains colloquially termed as 'Muri'. Imagine for a while that a cloth covers two square feet areas. In this situation if anyone tries to stretch it forcefully, cloth will be ruptured into several small pieces. Now multi-coloured pieces of cloths can be stitched for covering aforesaid area but a definite question may arise in mind that how strengthen it will be? Now focus on these small pieces of multi-coloured cloths. Improper dyes may release pigments and make dark stain and spreading out on entire cloth it may make a mess. Multi-coloured cloth can be compared with multi-cultural society. Within larger social order among various communities, diversity not always allows sober matching like dark stain on multi-coloured cloth. It is very difficult to draw a definite conclusion on future of multiculturalism; the ever changing socio-political situations always make uncertainty. There are several supportive examples of socio-political turmoil available in world literature. The etymology of multiculturalism definitely stands on those unpredictable changes. Most of the time it becomes very necessary to search out the root causes of multiculturalism from where its future can be guessed. The verb guessed is used here because there are several conditions, factors, barriers which make it more abstruse. Satisfactory cultural blending demands mental strength of sufficient adaptability, broadness of mind, tolerance in a required time frame. Otherwise apart from all gender biasness it can be said that it will be more abstruse to remove dark stain which occurs from implication of multilayered, multicolored diversity in society. Dark stain may be communal holocaust, riot, religious indifference and last of all terrorism, another endemic of present diversified society. Social 
anthropologists can enlighten us more about it but language of literature can portray these unwilling situations in its own manner.

\section{Boiling pot}

Worsen situations happen many a times repeatedly to fulfill 'self' or for unanimous collective interest. Day to day terrors have made certain imprint in public mind, terrorism has earned everyone's attention right from media personnel to common people and also of financial market. Literature lovers and authors, fine weavers of words, meanings and expressions are quite obviously no more any external entity. They are much concerned about this perturbed society as particles in boiling pot. So it is most unfortunate for us that discussing about terrorism one of the multi-cultural hazards is nothing but rewinding terrifying memories of past through literatures. Unfortunate because it can never be stopped by literal criticisms! Though it seems a gradual habit of adapting ineffective sense (blunt??) through literature which representing the hard core reality. The factuality wrapped by different colorful terms to hide our shameful faces or facts to avoid highly sensational and sentimental massacres and casualties and for maintaining communal harmony. How ridiculously strange behavior of mankind it is? But still literature portrays effect of multi culture or Cosmo culture or cross culture which may be the term that bypasses the true fact, the straight note, that hard talk. It elucidates the root meaning of terror and non-ethical (or ethical?) terrorism. Question may appear that is there any 'ism' at all in terror truly? That is another good topic of debate. But it can be said always with open mind at any open forum that compact bonding of literatures, literary criticisms, and debates on multicultural hazards like terrorism can never be permanent solution until we make habit of looking back at grass route level for searching the ultimate cause of terrorism. Literature can act here only as looking glass. What sort of truth then may come out? One of the answers is much known to everyone. Yes, never ever ending selfishness. Limitless uncontrolled ego, rigidity, greediness, aggressiveness, contradictions, conspiracies and violence are abject wings of inhumane approach.

From psychological point of view this dilemma, the mediocrity of human attitude might be root cause of such delirium termed as terrorism. Many of us who are still alive have witnessed terrifying destruction of 9/11 in USA or 26/11 in India once or twice in a lifetime and those who are not are really lucky enough. But there are many riots more violent than 9/11, happened in British India, British Africa and other countries those who were affected by colonial rules. Those are really vast chapters of history and nostalgic outcomes of literature. In country like India there are many such incidents where terrorism in musk of colonialism ruled over brutally for more than 200 years. That was not a matter of a day or a night. British may be offended but they cannot tamper the history of abominable despotism of East India Company. Eminent Historian, social activist, women's rights and democratic activist, former professor of The University of Delhi Smt. Uma Chakraborty has recalled her memoirs in book "Making a difference : Memoirs From The Women's Movement In India" about witness of colonial rule at her age of 5 years and shivering trauma of partition. She has written $-{ }^{\text {" }} \mathbf{B y}$ August 1947, there was mayhem in the streets. My brother and sisters literally 'witnessed' a killing as a group of three Muslim men ran toward police station for shelter. Two got there, the third didn't; the terror of that killing changed my sister.., always-looking-over-her-shoulder kind of girl who never recovered from the shock of that murder. A routine illness with high fever had me crying, "Why are the Hindus and Muslims killing each others?" in my delirium."1 Such kind of delirium is flickering of provoked terror but surely in different manner. Famous novel 'Pinjar' written by eminent Panjabi writer Amrita Pritam has drawn a portrait of unstable, hazardous and disturbed life of woman Puro resident of Chhattoani villege. Being from Muslim community she had gladly chosen Hindu fellow Ramchandra as her husband, her lifepartner firmly ignoring all social and racial conflicts and their limitations. In wider sense the title 'Pinjar' (The Cage) indicates dual meanings, one is helpless, confined situation of women before and after marriage in pre and post independent India and another is turmoil in captive India, the incident of partition and aftermath. More terrifying situation of East Pakistan and West Pakistan here two parts in boiling pot had been described in this novel. Amrita Pritam became very successful in visual rendering of riot and its panic where the after effect of terror actually exists. She had written - “.... Three half burnt bodies also evacuated, whose bodies were unwrapped with fat, whose burnt flesh were hanged separately from bones, whose ribs had been separated out from elbows and hinge joints. Those three died while people were taking position in Lorries. The Lorries proceeded leaving those three dead bodies. Their families remained screaming, crying but there was hardly any time for military to assassinate them." ${ }^{2}$ No doubt at all that absolute terrorism belongs to this description and this is happened not by any Islamic group who are extremely dedicated for 'Jihad' but behind it the cunningness and ultimate provocations of British government were strategically active. Their policies were to divide Bengal and Punjab, the places of intelligence and power. It's very clear that terrorism does not work only for extortion or hampering peace, it has a definite prolonged target. On that note it can be said that any sort of indulgence in prolificacy of terrorism must remain active on basis of madly religious fanaticism or by any revenge attitude with supreme despotism. Socio-economical or socio-political mottos are absolutely secondary priority in that case. Amrita Pritam had ample experience to witness racial vandalism at 
the terribly tough period of India Pakistan partition. In 'Pinjar' few more sentences should be mentioned to ruminate terrible situation for terrorism. She wrote - "The entire village of Puro remains empty. There was no one left of other races. Only three dead bodies were laid outside of mansion, whose rests of the flesh on ribs were ripped by village dogs and crows."3 Puro felt disturbed. So many questions arose at a time in her mind. She did not come into a decision that the huge land which is drenched by human blood will ever be fertile again for golden harvests. Will ever be spread out again sweet smell of corns as it was before? Puro was still in dark that will males of village ever stop maltreatment with sisters of their wives. Actually terrorism imprints so many marks with main flow. Indication of sexual exploitation is another sub-mark which was very much present in Puro's anxiety. Whenever critics will go for excoriation on terrorism moral laxness must be one of the important matters which can never be ignored. One of the female in the novel 'Pinjar' informed Puro that all Hindus of the village were waiting in a camp for next trip towards Hindustan by military. The military took care of this camp but at mid night a few Muslims used to come for kidnapping Hindu women. Unfortunately British India became no man's land of government sponsored terrorism.

Just imagine the situation that nobody is paying effort to touch bodies of victims after terrorist attack. Your beloved will also dare to touch your body after death. May be your soul will not attempt for a round where your dead body lies. Only flies with buzzing sounds of their wings and dreadful silence will observe you and other victims far from. Because of terrorist activities an unseen partition will make immediate distress, will make compartments in mindsets of victims and thus from common reflex of revenge partition of lands, partition of countries will unlock a new beginning of terrorizing others by same manner. At present time religious fanaticism has conducted evil thoughts of terrorism using sacrosanct perseverance in sake of religion and thus united effort comes to an end. But approximately seventy to eighty years back or more than that whatever incidents had happened in colonial India or African continent, seeds of today's terrorism were actually in sleeping mode at that time. Another example of terrorism in captive India in Hindi novel 'Kitne Pakistan' (Translated form of title would be 'How many Pakistan') by eminent Hindi author Kamleswar is no doubt remarkable to remember those terrifying days. Author depicted true history of India, the hidden cause of emerging terrorism, partition and unleashed killing of masses, the ultimate terrorism. In consequence of terrorism sudden death of many innocent, helpless people occurs as if their unbeatable destiny invites disasters, it may be incidents of $9 / 11$ or $26 / 11$ or may be of captive India shackled by British. If anyone has knowledge to annihilate 'death' or knowledge of overcoming it, that person will be completely capable to eradicate its consequent word terrorism forever from this eternal world. In 'Kitne Pakistan' author recounts the adventures of Gilgamesh, king of the ancient Mesopotamian city of Uruk, who was in his quest for immortality. He wanted to conquer on death. Kamaleswar had mentioned the name of King Gilgamesh in this novel, so that readers can recapitulate straight clash against evil and injustice in pre and early post independent India comparing with the job done by the King. Author had tried to open up more hidden secret as if these were the matters needed for discussion in open forum by different historic characters like Kabirdas, Mugal Emperor Alamgir Aurangzeb, Last viceroy of British India Lord Mountbatten according to their individual opinion and historical characteristics. It seems that novel is inviting us to go through hallucination. But the whole story is based on real truth, the hard core reality which has became a living history. Against colonial despotism Kabirdas raised his voice and charged allegation to Viceroy Mountbatten - “... so since year 1934 to 1937 British emperor had arranged programs with conspiracy.....not to delay more delayed independence of India, then divide India into two pieces.... Being a Muslim, Jinnah was not Muslim ....provoking in cupidity of a separate country Pakistan to all Tallukdar, minor and major Nawab and Jamindar (Land Lords) of North India the leadership of Mr. Jinnah is being managed....listen Mr. Mountbatten ...the decision of your Churchill Labor Government in House of Lords can be suspended...because in that case there was a majority of your ministers......and yours Britain at that time, after war was destructed and dying in hunger. Delaying the independence of Hindustan for more years you can manage right of exploitation!", Author had added some remarkable possibilities and incidents in context of those different arguments and statements. Such kinds of argumentative discussion among characters were not elusion. But it can be perceived that this was the exclusive way to bring out hidden truth of British government sponsored terrorism from prolonged discussions among these historical characters. Most funny thing is that according to historical chronology the confrontation among these characters seems to be the most impossible part in this novel but that was happened in skillful manner, convincingly and with successful expressions. It's not a novel of time shifting but a novel of time-space continuum. In court of Adib, Babar is being called. Babar told the truth that he did not invade to establish Islamic manifesto. He wanted a country. If he had any intension to destroy any Hindu temple he would have destroy Krishna Temple of Mathura first, would have gone to Ayodhya but from 'Babarnama' it was proved that he had never gone to Ayodhya. 'Babarnama' which was written on stone, was tamper by British which is now conserved in Archeological Survey of India. In sake of religion distress in between Hindu and Muslim had started from 1957. Babri Masjid and other civilizations have been attacked and few of them are demolished due to this politics of misunderstanding. Brahmanism, confrontation among white black in South Africa, lecture on 
freedom party all are incarnated in terrorism. "Kitne Pakistan" reminds us canning attitude of Viceroy Mountbatten. History says as per British and India circles Mountbatten was depicted as Super-statesman-cumPrince charming who solved the subcontinent's problem overnight through a combination of military forthrightness, sheer personality and tact. But the real fact is there was enormous exaggeration here. Mountbatten left many anomalies in arranging partition and totally failed to prevent the Punjab massacre. Actually for weakening India, a very bad intension of British imperialism was working very silently with breakneck speed and we do not have any hesitation at all to say that we are still facing problems for that divide and rule politics, one of the Tsunami for which not only India but the entire world is endangered. We should not forget birth of Pakistan was happened for that conspiracy of British imperialism and divide and rule hegemony. Freedom with partition at midnight disposed cruel choice between threat of sudden violence and squeezing of employment and economic opportunities over the years for too many Muslims in India and Hindus in Pakistan. People of both India and Pakistan generated the stream of refugees forcibly tearing out of age old roots. All the manifold human tragedies have been portrayed in "Pinjar", "Kitne Pakistan" as said before and also in "Jhuta Saach" by eminent Hindi author Yaspal, "Aadab" by eminent Bengali writer Samaresh Basu, "Nilkanto pakhir Khonje" by Aatin Bandopadhyay. We can also mention concerned movies "Garam Hawa" by Balraj Sahni.... Etc. "kitne Pakistan" begins with a romantic saga of Adib and Bidya. Both were students of Allahabad University. Adib was from Mainpuri and Bidya from Fatehpuri. Both of them used to travel another train from Kanpur for Allahabad. Once, Bidya said that she will not come from next year because her parents will not allow for more study. To catch the train for Fatehpuri she arrived in Kanpur. Coming down from overbridge she leaves her handkerchief. The train of Adib started moving. He could not catch the handkerchief and could not also miss the train. Like this each and every moment many dreams die before mature, many of us become failure to catch handkerchief, many Pakistan form unexpectedly. The indicative aspiration of author Kamaleswar was that where romance, love affairs become ruined, momentarily Pakistan forms, terrorism generates. Adib and Bidya never met again. Bidya went to Pakistan. Later on Salma came in life of Adib as his wife but somehow their relation did not persist at last. Salma and her son went away to Pakistan. Adib disheartened. This aftershock of divorce induced Adib to go through partition, bloodshed, Jinnah, Zia, Macaulay, Fort William College etc. and their presence and hospitality seemed to be dry, halfhearted and materialistic. Adib wanted to live with his second story, with his romance Bidya. But unfortunately Bidya lived in Pakistan being someone's third wife after marriage. At the end author Kamaleswar had shown consequently the bifurcated way of life of Adib and Bidya and partition of India. Our good senses of civil society may plant 'Bodhi Briksh' and this sort of utopia can never be important. There are many 'Sasank'(......) living in this society will never delay for a single moment to cut down that tree. Question may raise that will the king Gilgamesh appear at that time with life saving medicine to protect life of 'Bodhi Briksh', to stop desultory feet of death? "Kitne Pakistan" is a novel of time-space continuum. Such a continuum shows wide cult of terrorism, deformity of self-centered politics, exploitation of common civilian right from medieval era to modern period of India. The novel also states that many Pakistan are forming each and every moment in various parts of the world for terrorist activities. We have not take any lession from past. Otherwise incidents like 9/11 or 26/11 should not happen. To block homicidal trajectory Bush doctrine like others has equally very firm stand against terrorism. Former President of United States of America George Bush said - "There is no neutral ground between good and evil." It seems that difference between good and evil is very apparent. From recent past due to terrorist attacks there are so many unwanted incidents already happened, which shows same unchanged situation.

\section{Literature on Melting pot or Mosaic expressions}

Traditionally the United States has been described as a melting pot, a place where the previous identities of each immigrant group are melted down to create an integrated, uniform society. Since the 1960s, many Americans have rejected the melting pot metaphor in favor of the image of the mosaic, a picture created by assembling many small stones or tiles. In a mosaic, each piece retains its own distinctive identity, while contributing to a larger design. Advocates of the mosaic metaphor assert that it better represents the diverse multicultural society of the United States. Today, many Americans value their immigrant heritage as an important part of their identity. More recent immigrant groups from Asia, such as Vietnamese Americans and Korean Americans, have established communities alongside those populated by the descendants of European immigrants, such as French Americans, German Americans, Irish Americans, and Italian Americans. Forceful immigration in large scale had happened at the period of segregation of Bangladesh formerly East Pakistan and West Pakistan. Immigrants are known as Bangladeshi, commonly termed as 'Bangal'. Lot cultural and so as characteristic indifferences came up in day to day life, a further struggle began for residing in West Bengal. Immigrants from Bangladesh had faced many obstacles in their daily life and people of western part of Bengal suffered from thrust of huge unwanted population. Some critics may define the situation as an effect of crossculture but it's the end result of multiculturalism on bigger aspect. 
U.S. novelist Walter Mosley had once written in his novel 'Devil in a Blue Dress' - "I was in a black division but all the superior officers were white. I was trained how to kill men but white men weren't anxious to see a gun in my hands. They didn't want to see me spill white blood." 5 Let us envisage a human body having dismantled neck, attached with hinge of legs and fingers. It appears like ugly, handicapped, deformed and seems a frail effort of a quack craftsman on master craftsmanship. In spite of that some selfish, power loving people remain always active in this world behind any communal holocaust. They are devils in blue dress, roots of social turmoil. No doubt political interference spoils the whole situation. Among deprived classes revolting attitude of victims who have faced a lot trouble consistently from the beginning of their life reproduces mostly the concept of terrorism. But it may not be always the same. Religious fanaticism or superstition with political intervention can be another cause of the tragedy. Cultural diversity acts here as catalyst. Not one or two years, minimum few decades are required for proper cultural adaptation after any forceful assimilation. Obviously greatness of mind in that case is the rudimentary factor. Multi-culture then only will be capable to uphold a culturally enriched society as it always true for any lingual exchange for languages. On that note terrorism can be defined as grammatical mistake of multiculturalism. In this consequence 'The Kite Runner' written by eminent novelist Khaled Hosseini can be mentioned. The plot of the novel depicts the situation of seventy's Afghanistan where Russian invasion force the family of Amir to flee to America. Amir undergoes different experiences most of them are bitter and frightening not at all to be remembered especially meeting with Taliban goons and their uncivilized revolting attitude. The situation of each sector of Afghanistan remains same after four decades of bloodshed confrontation. Since long in ruined cities of Afghanistan, almost demolished buildings, damaged water pipelines, electricity polls of streets, haphazardly laid splinters and parts of grenades, mortars, closed schools, colleges, universities, shuttered religious and social events and occasions, multiculturalism stands here shamefully necked. Like Russian invasion dominance of American troops and continuous Taliban attacks no doubt had formed deformed mosaic expressions of culture badly effect in native Afghans. Here pictorial image of multi-culture can be enunciated as poisonous salad bowl on punk mosaic table. In version of Khaled - "Long before the Roussi army marched into Afghanistan, long before villages were burned and school destroyed, long before mines were planted like seeds of death and children buried in rock-piled graves, Kabul had become a city of ghosts for me. A city of hare lipped ghosts.......America was a river, roaring along, unmindful of the past. I could wade in this river, let my sins drown to the bottom; let the waters carry me someplace far. Someplace with no ghosts no memories and no sins." Amir from his childhood incidentally felt smell of multi-culture and imagined to wash away someplace far where no sins exist.

\section{Blending of multi-cultures and its intangible future}

It will be the most elusive and complicated to draw any concrete conclusion about blending of multiculture and its future. All the words constructed above are not at all sufficient because more and more discussions find lot of logical possibilities and introduce too much impossibility with never ending debates. For adjustable cultural blending much time is required with lot of changes in different socio-economical condition. But dominant cultures with aggressive behavioral changes have always basic instinct to take over recessive cultural factors. This transition period may be vibrant or may be disappointing, moments of apocalypse too. In most of the cases transition of cultural blending is not at all satisfactory; history produces these sorts of evidences repeatedly. Recalling past the term 'apartheid' can be mentioned which contains the meaning of separateness. The word silently enunciates snobby compartmental differences among black and white, general and subaltern, rich and poor, well off and deprived, aristocrat and commoners, have and have not's. Quality of a person, class or society here is completely negligible and theses constrains enhance to gear up process of cultural blending as most active catalysts in formation of multicultural multi-existence. A film was made by Anthony Fabian named 'Skin' in South Africa, based on biography of a lady struggler Sandra Laing who was born in family of Sannie Laing. Sannie and her husband both were white but because of some genetic disorder skin colour of Sannie's daughter Sandra was black. Sandra was very loving-child of her parents. The problem started first time in Sandra's life when parents send her in boarding school. Other boarders in hostel were not at all cooperative with Sandra because of her black skin like Negros. Moreover warden and class teacher also misbehaved with her. In class teacher used to humiliate her differentiating Black people and White people by demonstrating a chart - 'Black people are meant for farm workers, laborers and white people are for doctors, nurses'. Sandra could not adjust in hostel and could not resist such sort of mental torture. Even child Sandra could not understand colour apartheid, white, black culture. She was very shocked but this incident provoked her more and more to mix up with blacks, with Negro community and their culture. Sandra married Petrus Zwane, a black handsome against liking of her parents at very teen age. But her married life was not satisfactory. She struggled a lot, faced many insults and overcome many obstacles to stand by her own feet. Her parents refused to help her. 'Survival for the fittest' was perfect the proverb for Sandra Laing. She survived at 
last with seven grand children. A rainbow tuck shop was launched by Sandra. Two brothers of Sandra Leon and Adrian refused to reunite with her. The tragedy of Sandra's life indicates hatred in skin colour so as superiority complex, inadaptability of another class culture, multicultural hazards, in two words a racial policy - apartheid which portrays black part of human mind.

Think about a drum shaped blending machine to mix up cement, sand, stone chips and water for building a concrete slave or roof. Reader may think that I am going to speak on such blending machine which can mix up different cultures proportionately. A concrete multicultural blending is never possible like concrete slave because human minds are not like cement or stone chips. A balancing act with sufficient time is always required for sober cultural blending. We should keep in mind that it's very difficult to convince untamed minds under every unfavorable situation. Politics with basic needs, communal holocausts, military exercises, religious fundamentalism, terrorism and diplomatic partiality are inescapable impasses for satisfactory cultural blending.

In recent time countries which undergo various experiences of multiculturalism are Srilanka, Indonesia, Tibet, Maldives, Thyland to some extent Great Britain and of course United States of America. Now-a-days the term 'globalization' is known to all which can also be termed as 'Americanization'. According to free market policy it may be termed as 'Chinaization' in near future. John Updike the famous novelist in USA has written a novel 'Terrorist' emphasizing on effect of mixed culture or multi-culture, Americanization and religious Islamic fundamentalism with its fatal ending. The novel begins with a brief monologue by central character of the novel an American-born Muslim teenager named Ahmad Ashmawy Mulloy on the condition of American youth as represented by the student body mingling in the corridors of his high school. He gets into a fight with Tylenol who thinks Ahmad is flirting with his girlfriend Joryleen. Ahmad has sexual impulses toward the girl. He always tries to repress them because he believes that it is instruction of God. Ahmad starts the study of the Qur'an under the guidance of his imam and mentor Shaikh Rashid and finds solace at his mosque. He has a firm belief on his conviction because of the Shaikh Rashid has tendency to interpret the Prophet Muhammad's hadiths figuratively. Two important coincidental aspects around two characters in this novel are Ahmad's guidance counselor at New Prospect High School, Jack Levy an American Jew who maintains the stereotypical Jewish cynicism and depression and another one is Shaikh Rashid who tries to displays traces of skeptical mindset in hadiths and manipulates Ahmad into assisting in a bombing plot. Ahmad desires to become a truck driver on the advice of his Shaikh and trucking is also the path that leads involvement in a terrorist plot directed against the American "infidels" (non-Muslims) — an attempt to blow up the Lincoln Tunnel under the Hudson River. At the end of the novel Jack tries to convince Ahmed not to go through with the bombing. Ahmad reconsiders his interpretation of Islam deciding that God does not want him to kill anyone and aborts his terrorist mission. He and Jack ride through Manhattan together towards the George Washington Bridge to return to New Jersey. The plot of the novel provokes to look on certain multicultural characters like Ahmed's father an Egyptian immigrant who abandoned him and his mother when Ahmad was three years old, Teresa Mulloy, a thirdgeneration Catholic Irish American who has abandoned her religious beliefs. Egyptian immigrant father and Irish American mother representatives of two different cultures neglect their child Ahmed to look after. Surely a mental distress has been formed which provokes Ahmed more to believe on Shaikh Rashid, Imam and mentor of him. Multicultural blending here does not mature properly. It acts like distracted plates of earth under the earth which turns into an end result like Tsunami and terrorism in reality, a treacherous multicultural hazard. Untamed minds always show unpredictable behavior and this sort of behavior lacks to maintain balancing act especially at the transition state of unleashed multi-culture.

Is there anyone in this world who can read untamed minds and make proper justice, who can predict possibilities and hazards of multi-culture, who can understand the actual multicultural blending and who can erase dark stain of multi-cultured society? I have heard the name of Misir Ali, the miracle man. But miracle in what sense is he? Noted author of Bangladesh Humayuin Ahmed had portrayed ace character of Misir Ali in his popular novel 'Amei Misir Ali' (I am Misir Ali). Misir is such a wonderful character who tries to see the world closing his eyes. It's an astonishing fruitful believe and effort too of an intelligent man. He is also extraordinarily kind hearted, and emotional. Misir has said affirmatively - "I cannot and will not believe that man can be evil."7 Closing his eyes his inner vision can penetrate aphotic zone of superstitious, multi-cultured, delicate society and analyzing at the level of plunk dimension Misir may predict the future of multi-culture and crisscross untamed minds. Unfortunately Misir is missing in today's society. Is he really missing or unseen camouflage?

\section{Foot Notes:-}

1) The Statesman, $8^{\text {th }}$ Day, May 2012

2) Pinjar (The Cage) - Amrita Pritam, World pocket Books.

3) Pinjar (The Cage) - Amrita Pritam, World pocket Books.

4) Modern India (1985 - 1947) - Sumit Sarkar, Macmillan India Limited

5) Microsoft Encarta Dictionary

6) The Kite Runner - Khaled Hossaine

7) Robbar (Supplement of Pratidin, The News Daily) special issue on Humayun Ahamed 


\section{Reference Books:-}

[1]. Modern India (1985 - 1947) - Sumit Sarkar, Macmillan India Limited

[2]. From Plassey to Partition - Shekhar Bandopadhayay, Orient Blackswan

[3]. Kitne Pakistan - Kamleswar

[4]. Jhuta Sacch - Yaspal, Lokbharti Prakashan, Delhi

[5]. Nilkanto Pakhir Khonje - Atin Bandopadhayay, Dey's Publication, Kolkata

[6]. Adab - Samaresh Bose

[7]. Pinjar - Amrita Pritam, Hind pocket books, Delhi

[8]. Makers of Modern India - Ramchandra Guha, Viking / Penguin

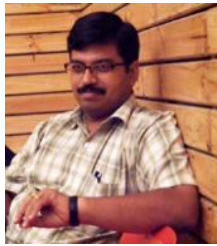

Dr. Anindya Gangopadhyay

Assistant Professor

Department of Hindi

Presidency University

Kolkata, West Bengal, India 